\title{
Measuring the Unmeasured: Cultural Heritage Studies in Honor of Prof. Francesco Forte
}

\author{
Michela Mantovani ${ }^{1}$
}

Published online: 3 February 2017

C) The Author(s) 2017. This article is published with open access at Springerlink.com

\begin{abstract}
This paper presents the contributions of Francesco Forte to the measurement of art and cultural goods and services, as I worked with him as his co-author. These contributions range from the valuation of art goods by the art matrix we conceived, to the valuation of the cultural welfare of nations, regions and local communities. Our work also assessed the provision of cultural welfare at the national, regional and local level for the public and non-profit sectors and measured the efficiency and effectiveness of museum bureaucracies. We also studied the profitability of investments in the arts by considering product life cycles, artistic movements and economies. More recently, with Michele Caputo, we focused on the long-run life cycle and success of the movie industry for select countries competing with foreign movie industries and TV entertainment by adopting Caputo's fractional derivatives theory, which captures the role of past history. Professor Forte and I also developed the Differential Touristic Development Index to measure the effects of art and cultural enterprises as tourist attractions. The most innovative contributions of Francesco Forte to the measurement of the economic value of cultural goods and services demonstrate that it is possible to "measure the unmeasured," and therein improve public collection of statistical data with the goal of increasing the preservation and valuation of cultural goods and services and highlighting their potential as economic multipliers.
\end{abstract}

Keywords Artwork evaluation - Endogenous and exogenous variables · Method fuzzy Product cycle theory $\cdot$ Investment in visual arts

JEL Classification Z00

Michela Mantovani

info@michelamantovani.com

1 Mediterranea University of Reggio Calabria, Salita Melissari, 89124 Reggio Calabria, RC, Italy 


\section{Assessment of Artistic Visual Arts}

\section{FM Art Matrix for the Valuation of Art Goods}

The first studies I did with Professor Francesco Forte were an assessment of artistic visual arts goods. We focused on artwork evaluation for private and public institutions (Forte and Mantovani 1998a, b, 1999a, b, 2000a, 2004; Mantovani 2001, 2008a, b; Forte et al. 2001). We developed the ForteMantovani (FM) art matrix to assign economic value and financial return to paintings. In addition, we developed other tools for art goods decision-making such as a fuzzy methodology to take care of non-quantitative variables and product cycle theory to assess the cycles of artist production and art schools according to the profitability of investments in visual arts. The FM art matrix, a variant of the Boston matrix, has four quadrants for high and low values and variable or stationary values (Table 1).

The Boston matrix helps financial investors and industrial companies better allocate resources. It is used as an analytical tool in brand marketing, product management, strategic management, and portfolio analysis. With the Boston matrix, investors can analyze the revenue streams of shares listed on the stock exchange (Mantovani 2008b). The FM matrix examines art products and capital values, capital gains and losses and, in some cases, current revenues. ${ }^{1}$

Cultural goods have an existence value and a use value. Their existence value may not be reflected in the market valuation. The use value, generally, for visual art goods does not manifest itself in monetary prices because either these goods belong to private owners, who enjoy their use directly, or they belong to a public or non-profit entity, which offers them to users at political prices or for free. Nevertheless, there is a market assessment of the use value through its capitalization by the market price assigned by collectors and art dealers (who work on supply and demand) and by art experts. One may also take into account the assessment by the public that visits art exhibits and museums measured by their visit frequency. The four-quadrant FM matrix depicts the capital value of the valuation on the vertical axis (medium to high versus low) and the variability of the valuation on the horizontal axis (high versus low).

\footnotetext{
${ }^{1}$ The Boston matrix, as a tool for managers, aims to give guidance on resource use associated with various activities. The parameters used for classification in this case refer to turnover. Rate of market growth is on the vertical axis and market share is on the horizontal axis which measures the firm's strength in that market. The combination of these two elements identifies four product groups or product lines: A problem child is a product with low market share in uncertain markets or potentially high growth in turnover and requires investment in order to grow. Stars are brilliant products with a high market share and are possibly still growing. They require investments that do not decay and possibly continue to grow, and then turn into cash cows. Cash cows are products that have constant turnover, given their good market share, but do not grow, because they are in low-growth markets and have established themselves as classics. Their name comes from the fact that, metaphorically, they are "cows" from which "milk" cash, gives life to the company and financing, if in debt, of other assets. A dog is a business with a low market share in a declining market. Dogs either generate just enough profits to break even or losses so management can eliminate them to thin the product range.
} 
Table 1 Forte-Mantovani art matrix

Variability

\begin{tabular}{|c|c|c|}
\hline \multirow[b]{3}{*}{ 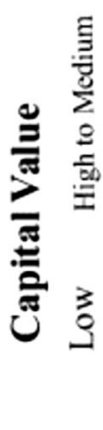 } & High & Low \\
\hline & $\begin{array}{l}\text { I STAR } \\
\text { Superstar } \\
\text { Stars } \\
\text { Starlets }\end{array}$ & $\begin{array}{l}\text { II BLUE CHIPS } \\
\text { Super chips } \\
\text { Top chips } \\
\text { Blue chip standard }\end{array}$ \\
\hline & $\begin{array}{l}\text { III QUESTIONS } \\
\text { Posible increase } \\
\text { Random } \\
\text { Posible decline } \\
\text { Lemons }\end{array}$ & $\begin{array}{l}\text { IV PORTFOLIOS AND DOGS } \\
\text { Portfolio High } \\
\text { Portfolio medium } \\
\text { Portfolio low } \\
\text { Portfolio miscellaneous } \\
\text { Dogs }\end{array}$ \\
\hline
\end{tabular}

STARS subcategories are superstar: \$/€50 million plus, star: \$/€20- 50 million, and starlet: $€ / \$ 5-20$ million. BLUE CHIP/CASH COW subcategories are super chips: $€ / \$ 1-5$ million, top chips: $€ / \$ 500,000-1$ million, and blue chip standard: \$/€ 250,000-500,000. PORTFOLIO and DOGS subcategories are high portfolio: $€ / \$ 100,000-250,000$, medium portfolio: $€ / \$ 30,000-100,000$, low portfolio: $€ / \$ 5,000-30,000$, mixed portfolio: $€ / \$ 2.500-5.000$, and dogs: less than $€ / \$ 2.500$ decrease. QUESTIONS subcategories are possible increase: works that now are probably undervalued, random: works with uncertain future value, possible decrease: works that presently are overvalued, and lemons: works with doubtful authenticity. Data source: Forte and Mantovani 2004, p. 609

\section{Vertical and Horizontal Variables of the FM Art Matrix}

In the top left quadrant of the matrix, art goods with high capital value and high variability are positioned. Art goods with medium value and low variability are categorized in the top right quadrant. In the bottom left quadrant, works of mediocre or low value subject to increases or decreases are placed. Finally, in the bottom right quadrant works with stationary, mediocre, or low value are listed.

In the top left quadrant, the star works, classified as super star, star, and starlets, are presented according to their value. They can move from one subcategory to another and, in some cases, fall into one of the right quadrants. The top right quadrant is where the blue chips and cash-cow works are placed, classified as super chips, top chips and blue chip standard depending on their value. Some of these are decayed stars. Others could become stars after market promotion.

The bottom left quadrant is the place for questions. These are works with unclear value, casual variations (random), or works of doubtful authenticity, which could be either fake or authentic. The bottom right quadrant is labelled portfolios and dogs. Portfolios are works that appear as mediocre low price investments. Dogs are bad works with no market value and no value to experts.

\section{Endogenous and Exogenous Variables}

Analyzing the economic value of artworks derived from prices achieved at international auctions, including 560 auction houses in 16 countries in 1985 (Art Sales Index 2007), 
we identified both endogenous and exogenous variables (Forte and Mantovani 1998b) that were relevant in determining economic value (Table 2).

The endogenous variables selected for the FM Art Matrix belong to three classes of factors inherent to the particular work: artistic values, hedonic values, and technical factors. The first class, artistic values, includes the author, his/her work, and the art movement to which the work belongs. The second class, hedonic factors, includes functional and practical values (such as those of a tapestry, mosaic or jewel), extraartistic information values (political and religious figures, portraits of famous persons, historic events) and pleasant sensations. The third class, technical factors, consists of dimension and materials, provenience (from a famous art collection, connection with other works), rarity, state of conservation, and existence of a signature.

We divided the exogenous variables into two classes regarding, respectively, macro socioeconomic variables and microeconomic variables relating to the different markets. The first class of exogenous variables includes national preferences and general political factors influencing public and private choices, socio-cultural trends, business cycles and macroeconomic trends. The class of microeconomic exogenous variables includes the institutions of the art markets, free trade and regulated markets, information flows, and marketing promotion practices.

The purpose of the value determination for an artistic work using the FM matrix is to provide central and local governments, museum managers, insurance companies, nonprofit entities, financial institutions, private investors, traders and experts with a manageable, objective, uniform method of evaluation. Our method of valuation implies an objective procedure with predefined steps for determining the value of artistic goods. The first step consists of assigning the good to one of the four matrix quadrants in order

Table 2 Linguistic variables: Forte/Mantovani model of artistic value

ENDOGENOUS VARIABLES

ARTISTIC VALUE

HEDONIC VALUE

TECHNICAL VALUE

EXOGENOUS VARIABLES

MACRO SOCIAL ECONOMIC FACTORS

MICRO MARKET FACTORS
1. Author

2. Work

3. Artistic movement

1. Extra artistic information value

2. Functional value

3. Semiological value

1. Dimensions of the material

2. Rarity

3. Origin

4. Signature, date, conservative status

1. National preference

2. Political and cultural trend

3. Macroeconomic cycle and trend

1. Regulated and Deregulated Markets

2. Informative flux

3. Artistic marketing 
to start the valuation process. This initial judgment provides basic indications about some macroscopic elements of value accepted at first glance, such as the recorded price realized in an auction by the artist. For works coming from authors never sold through auction, the assessor may classify the works, comparing them with similar works of authors sold at auction. The next step in the evaluation consists of finding the range of proper subclasses to which the work may belong by considering the relevance of the ten endogenous and six exogenous assessment variables. The third stage is the evaluation performed potentially using indicators derived from econometric analysis of existing datasets. Economists cannot take the place of an art expert, but can make important contributions regarding artistic value through empirical analysis.

\section{Fuzzy Set Method to Improve Valuation of Cultural Goods and Services}

To improve the assessment of the impact of qualitative variables on the economic value of cultural goods, as presented in our Art Matrix, we adopted the Fuzzy Set Method (Facchinetti et al. 2003), to determine the appropriate auction reserve prices. Indeed, this theory provides a systematic framework to deal with qualitative concepts expressed with linguistic logic translated into quantitative parameters by a complex system of variables using "fuzzy" relations. The term "fuzzy" means that there is an intrinsic lack of precision and uncertainty about the causal relationship between sets of qualitative inputs and outputs suitable for translation into crisp quantitative measures. The fuzzy logic procedure takes the form of a complex decision or assessment tree in which the sequences of linguistic variables extend their branches. In our case, the linguistic variable is derived from an assessment with several variables (i.e., a multiple attribute valuation [MAV] of art goods) so that the values the "fuzzy" method assigns to the art goods are ranges of values imputed to the linguistic variables. For the "defuzzification" into crisp variables for the FM art matrix, we adopted an interval of values between the minimum and maximum ranges with reference to statistics derived from past auctions in the international market.

The starting point requires assigning the art work to one of four main defined categories: stars, blue chips, portfolios dogs, and questions. For each category, the second step is the decision tree design. The linguistic classification may proceed differently for the stars and for authors belonging to the blue chips and portfolios. For the stars, it may be easier to identify from the outset the subclass or group of subclasses of linguistic variables to which they likely belong.

For the blue chips and portfolios, normally the MAV operation starts with identification of the general linguistic variable leading to a given quadrant, with the sub classification task remaining. For works identified as dogs, the MAV stops there. For lemons, it may be worthwhile proceeding further.

For the star, blue chips and portfolios, at the basis of the design are the main branches of the linguistic variables, which in the final evaluation involve artistic values, hedonic values, sociological macroeconomic factors, and microeconomic factors. These branches are not the final variables. Therefore, the simple decision trees with four branches can become large, with more than 30 independent branches by the end.

Practically, the initial distinction among quadrants implies that the MAV does not work with a unique system of parameters, such as for translation of inputs of linguistic variables into ranges of numerical values. The aggregation into rule blocs of intermediate variables differs in the various quadrants. 
The range of values in the FM art matrix is articulated by a decision tree which leaves the final choice up to the evaluator's judgment. The purpose of the evaluation is relevant. A reserve auction price implies a strategy of prudence requiring the selection of a value in the upper range, unless one needs to clean the auction.

\section{Product Cycle, Business Cycle and Investment in Visual Art and Long-Run Cycles of Movie Industry Development}

Works and productions of art and culture appreciation vary in relation to their life cycle and the historical period. Therefore, it is necessary to measure their value from a dynamic point of view. We applied product cycle theory to the valuation of works of art as well as to the fashion cycle and brands (Forte and Mantovani 2005).

Professor Forte and I observed quotations for the 20-year period 1977-1996 from four major art movements to identify the best performing movement (Forte and Mantovani 2004, p. 681-696). We considered the following movements: expressionism, surrealism, action painting ${ }^{2}$ and pop art (Mantovani 1997, 1999). Our studies showed that the first two artistic movements (expressionism and surrealism) had the same yield, around $6 \%$. The second group had a very high rate of return. Action painting had $8.9 \%$ and pop art had $11.75 \%$. For pop art, we choose Roy Lichtenstein, who is considered one of the most important pop artists. The initial years of his period were gray, but in the end, the price of his works of art increased with a return of $13.20 \%$.

With Michele Caputo, we further developed the theory of long-run life cycles and success of the movie industry of a given country competing with foreign movie industries and television. We used Caputo's theory of fractional derivatives, which captures the role of experience. We applied this theory to the Italian film industry (Caputo et al. 2014, 2015). We studied the development, decline and renaissance of the Italian film industry from 1966 to 2014 through an evolutionary model of two competing species, Italian and foreign movies, with memory formalism, which refers to the experience acquired and the reputation of firms in a given industry.

Should one invest in works of art? The answer from our point of view is yes. However, one has to choose the right piece of art at the right time. Art and business cycles, therefore, become relevant. To evaluate investment profit in visual arts, the buyer should consider art cycles, comparing prices with those in past auctions to determine whether it makes sense to buy, sell, or wait.

There is a positive relationship between art cycles and both real economic developments and the stock exchange expressed by the growth rate of gross domestic product

\footnotetext{
${ }^{2}$ The mediums considered were oils on canvas and acrylic on wood. The selection of artists of action paintings was carried out on the basis of Pasini Informale (1995). Artists of action painting from the U.S. include Willem De Kooning, Arshile Gorky, Franz Kline, Jackson Pollock, Ad Reinhardt, Mark Rothko, and Cy Twombly. Artists of action painting from France are Nicholas de Staël, Jean Dubuffet, Jean Fautrier, Hans Hartung, Georges Mathieu, Jean-Paul Riopelle, and Pierre Soulages. Artists of action painting from Italy are Afro Basaldella, Renato Birolli, Alberto Burri, Guiseppe Capogrossi, (Crippa), Lucio Fontana, Ennio Morlotti, Guilio Turcato, and Emilio Vedova. Artists of action painting from Spain are Antonio Saura and Antoni Tápies. Artists of the Cobra movement from Copenaghen, Brussels, and Amsterdam are: Karel Appel, Asger Jorn, and Guillaume Cornelis van Beverloo (Corneille).
} 
(GDP) in real terms, rate of increase (decrease) in the stock market index in real terms (deflated), and volatility of the stock exchange index (when available) for the various market areas considered. The micro information factors of are also important. An art lover or investor buying pieces of art and following the model we devised, taking account of these variables, may see increases in the value of the purchased works.

To assess art values considering GDP fluctuations, stock exchange behavior and inflation rates, we (Forte and Mantovani 1998b, 1999a, 2000a, 2004) adopted the following econometric model (Table 3):

$$
\Delta I=\alpha+\beta \Delta \log P I L-1+\gamma \pi+\delta \mu+\varepsilon V
$$

where $\alpha$ is the intercept, PIL is $1, P$ is delayed real GDP one year, $\pi$ is the inflation rate, $\mu$ is the stock market index in real terms, $I B V$ is the stock exchange weighted index relative to deregulated countries, $I B L$ is the stock exchange weighted index of nonregulated countries, and MSCI world is the World Stock Exchange index. $V$ is volatility weighted for major exchanges.

In order to assess the long-term value of investment in the arts, I built an index (Mantovani's index of the purchasing power of the duchy) of the value of the Kingdom of Naples' currency (the Ducato) in constant purchasing power, from 1647 to 1861, the year of annexation of the kingdom to the Italian one (Mantovani 2000a, b, c, 2001, 2002) and converted the Ducato into Italian lire at the official exchange rate (Forte and Mantovani 2004, pp. 642-643). ${ }^{3}$ Therefore, it was possible to convert the values in lire of the Ducato into euro at the official exchange rate adopted in 2001 . We converted the values of the Ducato, in constant purchasing power, for 1647 to 1861 in monetary unit values of other states existing in Italy before the unification, using the rates of exchanges then practiced. It was, thus, possible to assess the change in value of the art works traded in Italy and, more generally of Italian cultural goods and services, through centuries of the past.

\section{Cost Results and Cost Benefit Analysis of Cultural Goods and Services}

\section{Efficiency and Effectiveness of Museum Supplies}

To analyze the efficiency and effectiveness of museum supplies, Professor Forte and I (2000b) developed three indices of stock supply for recording situations, state of preservation, and exhibition. We also developed seven sets of indices relating flows of inputs and outputs, supply to the public and economic outcomes. The seven flow indices were for labor productivity, equipment availability, opening times, friendly services, visitor flows, consumer satisfaction and economic outcomes.

The recording situation index measures the shares of items of each museum's holdings that are listed, inventoried, catalogued, valued, photographed, and computerized. The state of preservation index consists of eight indicators, measuring the share of items that are subject to correct practice. Five of them are related to the item stored: 1) appropriate climate with proper light; 2) protection from fire and other natural damages;

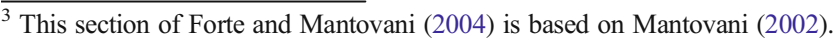


Table 3 Values of art and macroeconomic variables: Global

\begin{tabular}{llll}
\hline 1987-96 & Regulated countries & Deregulated countries & Total \\
GDP & 2.27 & 5.69 & 4.56 \\
Inflation rate & 3.98 & 5.25 & 5.07 \\
Stock Exchange & 2.15 & 4.21 & 3.6 \\
Stock Exchange Index & IBV & IBL & MSCI world \\
\hline
\end{tabular}

Source: Forte and Mantovani 1999a; 2000a, b; 2004)

3) high quality storage; 4) protection from theft and other human damage; and 5) items per cubic meter of storage space. Two indicators are related to items on exhibition: 1) appropriate preservation (light, temperature, humidity) and 2) protection from theft and damages.

The exhibition index consists of six indicators. The first indicator is the share of items exhibited of the total owned as a percentage of the national average of items permanently exhibited of the total owned. The second indicator consists of the share of items permanently exhibited plus those normally in storage or temporarily exhibited as a share of the national average. The third is the share of items exhibited in an average day. Two other indices relate to the number of items permanently exhibited and the total number of items exhibited in an average day per square meters of show area. The last indicator refers to the units of labor serving the visitors.

The indices of labor productivity and equipment availability concern the inputs. We suggest measuring labor productivity by six indicators of quantity output and two indicators of monetary costs. The six physical indicators of output per unit of labor are the number of cubic meters of storage, number of items recorded, square meters of show space, number of visitors, number of items shown, and number of items in special shows. The two cost indicators are labor costs as a percentage of total costs and number of paying visitors per unit of labor. The equipment availability indices measure the availability of technical equipment (such as computers), photographic and filming apparel and other technical apparel per unit of items served and per unit of labor.

Five opening time indices are related to the share of hours of operation. They are: 1) number of operating hours as a percentage of maximum operating hours; 2) number of operating hours on working days as a percentage of total working hours in a week; 3) share of operating hours on the weekends; 4) share of total operating hours devoted to evenings and festivities; and 5) share of total operating hours devoted to evenings, weekends, and festivities. Other indicators are related to the labor cost per hour of operation in general, labor cost per hour of operation for festivities and evenings, labor cost per hour of operation on weekends, labor cost per hour of operation for evenings, weekends, and festivities, and hourly labor cost per unit of visitors.

The visitor flow indices measure the ratio of each museum's visitors to the average visitors per museum at the national level, ratio of paying visitors, visitors on peak days, ratio of visitors on weekends and for festivities, young visitors, foreign visitors by nationality, language, and gender, and visitors by degree of education and profession.

The friendly services indicators include ease or difficulty of access, comfort indices relating to waiting time before entering, queues at ticket offices, crowding in showrooms, temperature, lighting, cleanliness, courtesy of the staff, stairs and elevators, 
visitors' guidance (scripts near the items in different languages, free illustrative material and expert guides capable of different languages), electronic connection with other rooms and other museums. Collateral services consist of primary services instrumental to the museum, such as restrooms and optional services such as a restaurant, gift shop, or boutiques. An index can be constructed to assess the friendliness of the access and visit, with indicators referring to the above facilities. Customer satisfaction indices can be calculated as collateral service revenue divided by admittance ticket revenue and compared to those of the best performing museums.

\section{Measures of the Contribution to National and Regional Welfare by the Cultural Stocks and Flows of the Public and Non-Profit Sectors}

To value the contribution to national, regional, and local art as well as cultural goods and services of public, non-profit and private entities, Professor Forte and I (Forte and Mantovani 2000b, 2001) developed indicators of national and regional stocks and flows of art and cultural goods (AC) (Forte and Mantovani 2001). The indices measure, for example, level of preservation of the stocks of AC, regional endowment of stocks of $\mathrm{AC}$ cultural welfare, performance in conservation, valorization and exhibition of $\mathrm{AC}$ stocks, flow of AC welfare, and level and territorial distribution of AC general welfare (Forte and Mantovani 2002b).

The stock of museum index is a rough index consisting of the number of items owned, classified into the four categories of works of art and history, archaeology, culture and library items. In an aggregation, we reduced by one-half the number of items in the culture category and by one-third those in the library item category because it seems likely that, on average, the market values of the stocks of arts and archaeology items are substantially greater than the stocks of items in the other categories. Thus, one may present a yearly index of the stock welfare for Italian state, regional and municipal museums.

Adding together the number of items in public museums, libraries and archives, corrected as suggested above, we presented an index of the stock of AC with four classes of indicators consisting of art (and history) items, archaeological stock, cultural items in museum sites and archives, and library stock in museums and libraries. Adding together the items in the first two classes and those in the last two classes, we constructed an index of stock ownership. Then, one could construct an index of regional endowment by raking the endowment of $\mathrm{AC}$ stock per inhabitant of each region, normalized to the per capita endowment of the better performing region of each of the four (or two) classes.

Regarding performance in the preservation of AC stocks, we constructed a composite index for the state museum's art and cultural goods and for state libraries and archives based on optimality criteria, proceeding as follows. For inventory, a satisfactory index is $100 \%$ of the items owned. For cataloguing museum art and archeological goods, the appropriate level is $50 \%$. For other goods, the appropriate level is $100 \%$. We can measure the degree of achievement for each region by the average of the distances to the assigned target for the two scales of inventory and cataloguing, and for the three classes of arts, archaeology and cultural stock. For the ratio between items owned and those shown in museums, $100 \%$ may not be appropriate because preservation is also part of their mission. 
For some items, documentation, reproduction and the possibility of permanent consultation by the media may be adequate, so that the collection is available to the community in general. A permanent exhibition could damage the goods to be preserved. Though a long-run objective may be the eventual display of all items, achievement of this objective may be attained best by only temporarily showing the part of the collection that cannot easily withstand permanent public exposition without damage. All other items could be readily considered for permanent or quasi-permanent exhibition.

It should be noted, however, that there is a relationship between the market valorization of given artists and art works and the degree of knowledge diffusion. Therefore, museum exhibition strategies must also consider the valorization of the stock of artistic works owned.

For the flows of $\mathrm{AC}$ welfare by museums, theaters and similar institutions, visitors and spectators becomes relevant (Forte and Mantovani 2010). In this respect, the distinction between paying and free consumers is important, as is the subsidy per head. Another relevant item is the distinction between domestic and foreign consumers and between resident and non-resident consumption because the flow of non-resident consumers contributes to local welfare through tourism expenditures.

On the supply side for museums, it is important for them to be open on weekends and (perhaps) in the evenings. The visit timing may be predetermined, so that visitor flows are rationalized. The relationship between average prices and the flow may also be an interesting indicator of the impact of supply policy on welfare. For theaters on the supply side, the number of shows and performances, in terms of new shows and performances are all important. An index of the relationship between the average price and number of customers may be a useful tool.

Yearly data related to the flow of consumption on the demand and supply side have a peculiar function excluding stock, that of measuring a component of welfare enjoyed in the year, imperfectly represented in GDP. However, it is not easy to provide synthetic indicators of the aggregate flow of AC welfare in physical terms.

Focusing on the arts, flows and stocks are not determined from an artistic point of view, for concerts, operas, and dramas, because they may be performed by companies that have different artistic values. Even indicators that appear similar, such as the number of spectators compared with the number of visitors of museum sites, may constitute proxies of different phenomena. The personal services supplied to a spectator at a high quality concert during concert season are different from those of medium quality. These differ from the services supplied to the visitor of an average museum open the entire year.

For the available years from 1990 to 2000, we constructed an index of Italian star artistic welfare, based on the performance of 20 star museums and six star Italian theaters. We classified the 20 star museum sites into the three categories of art, archaeology and culture. This last category includes sites such as royal palaces, historical buildings and villas with gardens. We categorized the performances of the star theaters into the three categories of lyrics, concerts, and ballet and others.

For star museums, we considered as indicators the number of visitors in general, paying visitors, and free visitors. For star theaters, we considered, for each of the three categories, the number of tickets sold and number of performances. For lyrics, we considered on the supply side the execution of new operas. To have a general 
composite index of AC welfare flows in the various years across regions, we suggested a six category classification: 1) music, 2) movies and theatrical representations, 3) publications, 4) visual arts, 5) archaeology, and 6) historical and scientific culture, with selective indicators as proxies of the entire spectrum.

Professor Alan Peacock (Peacock 2003) commented on our study as follows:

“The problem of defining and measuring 'success' is writ large in the case of that important institution, government, and particularly so in the case of cultural objectives. As Forte and Mantovani (2002 forthcoming) in a fundamental paper make clear [...] Any form of government financial support to cultural activities, whether to private or to state-owned and operated organizations, requires procedures which represent techniques of appraisal. Indeed, the rationale of the collection and assimilation of data representing the value and volume of cultural change lies in being able to use these data to check on whether the performance of the grant-receiving bodies accords with expectations. At the practical level this entails some form of contract between the government agency offering finance and the recipient. An important element in such a contract is some form of monitoring of the recipient's performance. Performance indicators of varying degrees of sophistication are used by bodies such as arts councils and commissions acting as agencies of government (pp. 1-2)."

\section{Cultural Goods as Tourism Attractors: Differential Tourist Development Index}

In order to measure the effects of cultural goods as tourist attractors (Mantovani 2000c, 2003, 2008a, 2010b, 2010c, 2011; Forte and Mantovani 2002a), Professor Forte and I conceived the Differential Tourist Development Index (DTDI) measuring touristic development of the locality concerned $\left(D T D_{L}\right)$, compared to those of other areas as a benchmark reference of which it forms a part, in particular the region $\left(D T D_{R}\right)$ and the nation $\left(D T D_{N}\right)$ (Mantovani 2010a, 2011, 2014). The index consists of two pairs of indicators: tourist offer $(T O)$ and tourist flows $(T F)$, respectively, relating to the offer of accommodation for tourists and the effective demand for tourism, consisting of tourist flows.

To build the $T O$ index, two components have to be considered: the arithmetic mean of the number of accommodation services, divided by the square kilometers of the considered area, and the number of beds divided by year-round residents. For the composite $T F$ index, the arithmetic average of the arrivals was divided by the square kilometers and the resident population, respectively.

The index of tourist attractions in a location $\left(T O_{L}\right)$ is calculated as:

$$
T O_{L}=\left(T E_{L}+T B_{L}\right) / 2
$$

where our measure of the rate of entrepreneurship $\left(T E_{L}\right)=$ the number of tourist accommodation services in relation to the kilometers of the territory $\left(E_{L} / K_{L}\right)$ and our 
measure of bed capacity $\left(T B_{L}\right)=$ bed accommodation services in relation to the population $\left(B_{L} / P_{L}\right)$.

The index of intensity of tourist flows $\left(T F_{L}\right)$ is calculated as:

$$
T F_{L}=\left(T A_{L}+T V_{L}\right) / 2
$$

where $T A_{L}=$ tourist arrivals in the territory $\left(T A_{L} / K_{L}\right)$ and $T V_{L}=$ number of visitors in relation to the population $T V_{L} / P L$.

The touristic development $(T D)$ index is calculated as $T D_{L}=\left(T O_{L}+T F_{L}\right) / 2 . D T D_{L R}$ is the differential tourism development of the locality $(L)$ with respect to the region and is calculated as $D T D_{L R}=T D_{L}-T D_{R}$. $D T D_{L N}$ is differential tourism development of $L$ with respect to the country $(N)$ and is calculated as $D T D_{L N}=T D L-T D N$.

\section{Application of the DTDI to Location of Movies, Star Theaters and Artists}

I applied the DTDI (Mantovani 2010a, 2014) in order to analyze the significant economic impact on the province of Ragusa (Sicily) after a television series titled "Detective Montalbano" was broadcasted from 1999 to 2012. I used the range between 1999 and 2012, with 1999 as the base year, in order to identify the "Montalbano effect," becoming effective after 2000 .

In 13 years, the DFDI TD (Table 4) showed a significant increase of $375 \%$ in Ragusa, compared to $190 \%$ for Sicily and $153 \%$ for Italy. Accommodation services have increased almost 10 times in Ragusa, 2.6 times in Sicily, and 1.27 times in Italy. Compared to Sicily and Ragusa, Italy has lower indicators of development, with the exception of the $T F$ index (129\% for Italy, $119 \%$ Sicily and $124 \%$ for Ragusa).

The disaggregation of $T F$ in Table 5 shows television grew slightly: Italy $118 \%$, Sicily $119 \%$ and Ragusa $117 \%$. Yet, it is difficult to certify presence, as some cottages and bed and breakfasts are not required to record their existence, or even worse, some business owners used public funds to convert rural buildings into accommodation facilities which were never used for the stated purpose. TO increased by $177 \%$ in Italy, 260\% in Sicily, and $627 \%$ in Ragusa (Table 4). This shows that our composite index is reliable, registering the largest increase of enterprises and beds, because we used tax data. Particularly in Italy (Table 5), the rate of entrepreneurship (TE) has grown by $227 \%$, less than Sicily with $361 \%$, while in Ragusa it has had an exponential increase of $1073 \%$ (about 10 times). The companies in Italy have been less dynamic than what has happened in Ragusa. These new forms of receptivity are more flexible. Italy has not witnessed an impulse comparable to the so-called "Montalbano effect," as Ragusa has.

Table 4 Differential tourism development index

\begin{tabular}{llll}
\hline SITES & TO & TF & TD \\
ITALIA & $177 \%$ & $129 \%$ & $153 \%$ \\
SICILIA & $260 \%$ & $119 \%$ & $190 \%$ \\
RAGUSA & $627 \%$ & $124 \%$ & $375 \%$ \\
\hline
\end{tabular}


Table 5 Disaggregated $T O$ and $T F$

\begin{tabular}{lllll}
\hline & \multicolumn{2}{l}{ Tourism Offer (TO) Enterprises } & \multicolumn{2}{l}{ Tourism Demand (TF) } \\
SITES & TE All & Beds TB & Arrivals TA & Presence TV \\
ITALIA & $227 \%$ & $126 \%$ & $140 \%$ & $118 \%$ \\
SICILIA & $361 \%$ & $159 \%$ & $120 \%$ & $119 \%$ \\
RAGUSA & $1073 \%$ & $180 \%$ & $131 \%$ & $117 \%$ \\
\hline
\end{tabular}

Source: Mantovani 2010a; Mantovani 2014

Our index, which refers to the existence of accommodation with arithmetic means, detects these unregistered businesses and thus avoids the problem of underestimation. This study shows that Ragusa is still underdeveloped in terms of its opportunities for growth, as it captures the tourists only for the time needed to visit the film-related places. It should be noted that the villages and towns belonging to the Province of Ragusa that were in decline, while valued for their historic and artistic significance, have regained life. It is for this reason that the number of residents in Ragusa, as in Italy, has increased, contrary to Sicily. In fact, while Ragusa and Italy have had an increase of $0.04 \%$ in residents, Sicily has had a decrease of inhabitants of $0.02 \%$. This might suggest that Sicily has always been a land of emigration to northern Italy or abroad. The Province of Ragusa was successful, thanks to this television fiction-related development of the area, in stopping this flow by offering job opportunities in the field of tourism and all the activities related to it, ranging from catering to transport, communications, financial services, or education. There has also been an increase in the value of real estate.

\section{Why the DTDI is Useful}

If one considers, as many experts do, only the temporal trend of the indexes of the local tourism industry when looking at the effects of an intervention on the dynamics of local tourism, one is wrong, because any variation observed, positive or negative, may depend on exogenous factors. Only the DFDI allows us to understand if in the considered province there is a phenomenon that generates better performance, not only compared to past times, but also compared to the behavior of other tourist areas. In this case, there is a "Montalbano effect."

\section{Concluding Remarks}

Art and cultural goods and services are goods endowed with an economic value relative to their appreciation in the market where not only private collectors, but also nonprofits and public institutions, expressing social valuation operate as purchasers and sellers. The economic valuation of these goods, in monetary terms, even with value ranges rather than crisp valuations, improves public finance options regarding their acquisition, preservation and valorization and opens the way to cost-benefit analysis of these activities. On the other hand, as many services of public institutions of art and culture, such as museums, are free of charge or underpriced, it would be wrong to 
measure their results in monetary terms. It is important to develop alternative measures to value their services (Forte and Mantovani 2010).

As market economy firms may develop physical indicators of input and outputs to plan activities for their organization, the same should apply to managers of non-market institutions that provide public sector cultural services, such as museums, theaters, orchestras, public libraries, and public archives. This valuation permits efficiency improvement. In addition, valuation permits measurement of the output of public art and cultural services, for each district, region and country where the services are available. Measurement of the cultural welfare produced by the public economy is also possible.

Art and cultural goods not only produce cultural welfare to the community. They also increase economic welfare in other sectors by acting as attractors of tourist flows and commerce. Two cases, in particular, deserve attention: promotion of movie locations and performances of theatrical shows of highly creative artistic quality, to promote visits to these communities, productions and brands.

The contributions of Professor Forte to these themes of valuation show that it is possible to "measure the unmeasured" values of cultural heritage and other cultural goods and services. It is possible to improve their preservation and valorization and their potential as economic multipliers. I was honored to collaborate with Professor Forte in these endeavors.

Open Access This article is distributed under the terms of the Creative Commons Attribution 4.0 International License (http://creativecommons.org/licenses/by/4.0/), which permits unrestricted use, distribution, and reproduction in any medium, provided you give appropriate credit to the original author(s) and the source, provide a link to the Creative Commons license, and indicate if changes were made.

\section{References}

Art Sales Index CD-ROM. (2007) edited by Duncan Hislop. Art Sales Index, Ltd., Egham, Surrey, England, 2005. Caputo, M., Forte, F., Mantovani, M. (2014) Cognitive dissonance, efficient and inefficient rent seeking and public aid to the movies (Forte F) (edited by Forte F., Mudambi R, Navarra P.M) Handbook of Alternative Theories of Public Edward Elgar Publishing Inc. 413-449.

Caputo, M., Forte, F., Mantovani, M. (2015). An evolutionary model of two competing Species with a memory formalism, applied to the Italian Movies industries to assess the effects of the Policies for its promotion, (Caputo M, Forte F), in: Jungen Backhaus, Taking up the Challenge, Helge Peukert, (Germany). 1;53-87.

Facchinetti, G., Forte, F., Mantovani, M., \& Mastroleo, G. (2003). A fuzzy expert system for auction reserve price in Soldek J.\& Drobiazgiewicz L. (2003) Artificial intelligence \& security in computing systems. Norwell: Kluwer Academic publisher.

Forte, F., \& Mantovani, M. (1998a). L'investimento nell'arte sul mercato internazionale libero e in quello italiano regolamentato. (Art investments in the international free market and the regulated Italian market.). Il Risparmio, 46(1), 45-69.

Forte, F., \& Mantovani, M. (1998b). Il Patrimonio culturale pubblico: alcune riflessioni sulla sua valutazione e sul ruolo dell'informazione. (Public cultural heritage. Some thoughts on its valuation and on the role of information), Moneta e Credito. 331-362.

Forte, F., \& Mantovani, M. (1999a). La valutazione dei beni artistici nelle strategie delle Fondazioni bancarie. (Art goods valuation in bank foundation strategy). Fondazioni Supplemento alla Rivista Il Risparmio, 48(1), 65-93.

Forte, F., \& Mantovani, M. (1999b). La valutazione dei beni artistici nel patrimonio delle Fondazioni museal (Arts goods' evaluation in the patrimony of museums' foundations. Rivista Italiana di Economia, Demografia e Statistica, 53(3), 9-46.

Forte, F., \& Mantovani, M. (2000a). Il valore economico delle opere d'arte. (The economic value of artworks). Economia della Culturan, 3, 333-345. 
Forte, F., \& Mantovani, M. (2000b). Efficiency and effectiveness of museums supply in an agency context. Studi Economici n, 71(2000/2), 5-76.

Forte, F., \& Mantovani, M. (2001). Measures of art and cultural welfare methodological and empirical aspects, New Economic Windows Conference, Salerno September 2001.

Forte, F., \& Mantovani, M. (2002). Le politiche di valorizzazione e marketing per le varie tipologie di dimore storiche (a cura di Trupiano G) Problemi di valorizzazione, gestione finanziamento dell'offerta culturale Biblink editori Roma (IT).

Forte, F., \& Mantovani (2002). Nuovi principi e nuove opportunità nelle regolamentazioni dei servizi pubblici locali. Un analisi Economica. (F. Forte) ANCI rivista (mensile dell' Associazione nazionale dei comuni italiani) n. 6 giugno 2002, n.7 luglio 2002, n.8 agosto 2002, n.9 settembre 2002.

Forte, F., \& Mantovani, M. (2004). Manuale di economia e politica dei beni culturali (Handbook of economics and economic policy of cultural goods). Rubbettino: Soveria Mannelli.

Forte, F., \& Mantovani, M. (2005). Lezioni di economia della moda e della marca. (Economics of fashion and brand lectures). Torino: Giappichelli.

Forte, F., \& Mantovani, M. (2010). Regional policies for the cultural heritage of Calabria and in the framework of the incentives of the'EU Institutions 2000-2006 and proposals for reform (A project for Calabria) (edited by A. Spadaro) Jovine publisher 2010 Naples. 841-868.

Forte, F., \& Mantovani, M., et al. (2001). Offerta di Beni artistici e storici, distretti d'arte e flussi turistici (F. Forte). In P. Valentino \& G. Mossetto (Eds.), Museo contro museo. Le strategie, gli strumenti I risultati Quinto Rapporto Annuale dell' Associazione Culturale Civita (pp. 153-170). Firenze: Giunti.

Informale, P. R. (1995). L'Informale.Stati Uniti Europa Italia, clueb, Bologna.

Mantovani, M. (1997). Saggio sull'informale bolognese in Review, Bologna anni 50-90, assieme a vari studiosi dell'Università di Bologna.

Mantovani, M. (1999). Le Fondazioni e le arti visive negli Stati Uniti in Fondazioni supplemento della rivista Il Risparmio 3-4. 63-68, Giuffrè editore.

Mantovani, M. (2000). Art goods as public goods and merit goods in the kingdom of Naples, of XVII-XIX Century, Politeia rivista di Etica e scelte pubbliche n. 59. 86-102.

Mantovani, M. (2000). Potere d'acquisto della moneta 1647/1861 in lire attuali ed economia pubblica nel Regno di Napoli in Studi per una rivalutazione economica e culturale del Mezzogiorno. Moneta ed economia pubblica nel Regno di Napoli e politiche dei beni culturali nell' area napoletana n.69, collana "Contributi per la discussione", Milano, Politeia. 1-74.

Mantovani, M. (2000). Le ville vesuviane del '700 napoletano come bene pubblico dell'economia privata in Economia della Cultura (Il mulino) n. 1. 95-105.

Mantovani, M. (2001). Potere d'acquisto del ducato 1647/1861 in lire attuali ed economia pubblica nel Regno di Napoli in Rivista italiana di economia demografia e statistica volume LV n ${ }^{\circ} 1 / 2001$. 111-161.

Mantovani, M. (2002). Art in the economic history of the kingdom of Naples, from the eighteenth to the nineteenth century. Journal of European Economic History Capitalia Gruppo Bancario, 31(1), 159-181.

Mantovani, M. (2003). Un itinerario turistico culturale: le Ville Vesuviane del '700. 399-443 Annali 2001-02 della Facoltà di Economia Roma "La Sapienza.

Mantovani, M. (2008). Alcune riflessioni sulla politica fiscale per i distretti turistici e culturali in Annali 2006 Facoltà Economia Roma "La Sapienza". 229-266.

Mantovani, M. (2008b). Un nuovo metodo su basi empiriche per la valutazione economica dei beni artistici del patrimonio pubblico (A new method on empirical basis for the economic valuation of the arts goods' in public patrimony), in Brosio G.(ed),(2008). 259-289.

Mantovani, M. (2010). Produzioni cinematografiche e turismo. Le politiche pubbliche per la localizzazione cinematografica. Il caso del commissario Montalbano (Movie productions and tourism. Public policies for movie location. The case of Commissario Montalbano), Rivista di scienze del turismo, I, 3, 2010.81-103. Led, Milano.

Mantovani, M. (2010) I caratteri distintivi delle dimore storiche Le dimore storiche.Quadrimestrale d'arte dell' associazione dimore storiche italiane. 2/2010. 27-35.

Mantovani, M. (2010) Il nodo delle ville venete Le dimore storiche. Quadrimestrale d'arte dell' associazione dimore storiche italiane. 1/2010. 27-35.

Mantovani, M. (2011). Beni culturali e la creatività artistica come attrattori turistici. Il caso Zeffirelli per l'Arena di Verona, (Cultural goods and artistic creativity as tourist attractors: the Zaffirelli case for di Verona's Arena) in Cannizzaro S. (ed.). 211-228.

Mantovani, M. (2014) Scientific Symposium, International Council of Monuments and Sites (ICOMOS) Heritage and Landscape as Human Values Florence, Italy, November 2014, "Movie-induced tourism: Detective Montalbano TV fiction as a tourist's experience in Sicily. Not published.

Peacock, A. T. (2003). Performance Indicators and cultural policy. Economia Della Cultura, 13, 1-13. 